\title{
The effect of variable turbulent intensities on the distribution of zooplankton in the shallow, large Lake Balaton (Hungary)
}

\author{
E. Baranyai ${ }^{(1,2)}$, L. G.-Tóth ${ }^{(2,3)}$, A. Vári(2), Z.G. Homonnay ${ }^{(4)}$ \\ Received September 6, 2010 / Reçu le 6 septembre 2010 \\ Revised January 5, 2011 / Révisé le 5 janvier 2011 \\ Accepted January 10, 2011 / Accepté le 10 janvier 2011
}

\begin{abstract}
Key-words: The influence of current velocity on zooplankton organisms is manifold. Balaton, vertical migration, current velocity, zooplankton Moderate current velocity is beneficial for zooplankton, but through various mechanisms too high a current velocity can have detrimental effects. We examined how current velocity acts on zooplankton in Lake Balaton at different levels and found a highly significant, negative relation between current velocity and the density of zooplankton assemblages. Of the studied assemblages, Daphnia galeata $\times$ cucullata and Eudiaptomus gracilis exhibited the greatest sensitivity to the degree of current velocity. During calm weather, when the water surface was calm too, nocturnal migration was observed for both Daphnia galeata $\times$ cucullata and Eudiaptomus gracilis. We demonstrated that the vertical migration of these two species started before the storm as the usual nocturnal migration, but during the storm the regular pattern was confused.
\end{abstract}

\section{ABSTRACT}

\section{RÉSUMÉ}

L'effet d'intensités de turbulence variables sur la distribution du zooplancton dans le Balaton (Hongrie), grand lac peu profond

Mots-clés :

Balaton, migration verticale, vitesse de courant, zooplancton
L'influence de la vitesse du courant sur les organismes zooplanctoniques est variée. Une vitesse de courant modérée est bénéfique au zooplancton, mais par des mécanismes divers un courant fort peut avoir également des effets néfastes. Nous avons étudié comment la vitesse du courant agit sur le zooplancton dans le lac Balaton à différents niveaux et avons trouvé une relation significativement négative entre la vitesse du courant et la densité des assemblages zooplanctoniques. Parmi les espèces étudiées, Daphnia galeata $\times$ cucullata et Eudiaptomus gracilis montrent la plus forte sensibilité à la vitesse du courant. Par temps calme, quand la surface de l'eau est plate, une migration nocturne est observée aussi bien pour Daphnia galeata $\times$ cucullata que pour Eudiaptomus gracilis. Nous avons montré que la migration verticale de ces deux espèces démarre avant la tempête comme la migration nocturne usuelle, mais pendant la tempête le schéma habituel est brouillé.

(1) University of Pannonia, Department of Limnology, Egyetem u. 10., 8200 Veszprém, Hungary, eszter.baranyai@freemail.hu

(2) Hungarian Academy of Sciences, Balaton Limnological Research Institute, Klebelsberg Kuno út 3., 8237 Tihany, Hungary

(3) Szent István University, Faculty of Economics and Social Sciences, Institute of Regional Economics and Rural Development, Práter Karoly u. 1., 2103 Gödöllo, Hungary

(4) Eötvös Loránd University, Department of Microbiology, Egyetem tér 1-3., 1053 Budapest, Hungary 


\section{INTRODUCTION}

The type of vertical migration of zooplankton depends on both species and their habitats; moreover, within one population it may differ between individuals of different ages, larval stages and genders, and it may exhibit seasonality. The most common migrational pattern is nocturnal migration, which consists of an upward migration towards the water surface at dusk and a downward movement at dawn. Consequently, most individuals can be found close to the surface during the night. In certain cases, a reversed migration can be observed, when high densities can be found close to the surface during the daytime. Several other migration patterns are known, such as twilight migration, consisting of concentration at the surface twice a day: at dusk and at dawn (Cushing, 1951; Hutchinson, 1967; Wetzel, 1975; Raymont, 1983).

Earlier research attributed the vertical distribution and migration of zooplankton mainly to photo- and geotaxis (Ringelberg, 1987, 1999; De Meester, 1993; Moore et al., 2000). These authors mention behavioral patterns which can be observed in activity and swimming (Folt and Burns, 1999), and passive transport due to wind-induced currents and turbulence (George and Winfield, 2000). Several studies proved that orientation along horizontal and vertical gradients of temperature or nutrient concentration also plays a major role (George, 1983; Lampert et al., 2003). One of the reasons for diel vertical migration mentioned in the literature (Zaret and Suffern, 1976; Stich and Lampert, 1981; Kvam and Kleiven, 1995) is avoidance of predation, which is supported by the observation that some zooplankton species were shown to perceive fish kairomones with their chemoreceptors (Tátrai and de Bernardi, 1992; Van Gool and Ringelberg, 1998; Ringelberg, 2000; Hülsmann et al., 2004; Van Donk, 2006). The relative change in light intensity was observed to be responsible for the movement direction of some Daphnia species (Ringelberg, 1987, 1999; Van Gool and Ringelberg, 1998; Moore et al., 2000). Some authors found that wind-induced internal waves influenced the vertical distribution of zooplankton (Megard et al., 1997; Easton and Gophen, 2003; Rinke et al., 2007).

Lake Balaton is the largest shallow lake in Central Europe (area: $596 \mathrm{~km}^{2}$, mean depth: 3.25 m). Earlier studies (Daday, 1884; Entz and Sebestyén, 1942) of zooplankton in Lake Balaton reported the concentration of some copepods and cladocerans in the water layers close to the surface in calm but overcast weather, and moreover they demonstrated that storms homogenized the assemblages along the depth.

Sebestyén (1933) stated that the lower boundary of the vertical distribution of Leptodora kindtii (Cladocera) in Lake Balaton is frequently close to the lake bottom, but diel changes could only be detected in the upper 1.5-m layer. She observed that the diel pattern changed when wave action was stronger, and she also hypothesized that diel vertical migration is driven by the changing of light conditions (Sebestyén, 1933).

In research conducted by Ponyi and Péter (1986) in periods without long-lasting winds or waves, the majority of the copepodit stages and adults of Eudiaptomus gracilis (Copepoda, Calanoida) in Lake Balaton were found at a water depth of $1 \mathrm{~m}$ during the day and the population was uniformly distributed in the whole water column in the night. Nauplii remained close to the surface by day but, as a consequence of intense downward migration, dispersed more evenly during the night (Ponyi and Péter, 1986).

In the Inner Lake of the Tihany Peninsula of Lake Balaton, which is also a shallow lake with a mean depth of $1.5 \mathrm{~m}$, diel migration of Copepoda and Cladocera could also be divided into two periods: concentrating at depth by day but migrating upwards at night (Ponyi and Tamás, 1964).

The inorganic seston content of Lake Balaton is $25 \mathrm{mg} \cdot \mathrm{L}^{-1}$ dry mass on average, and during storms it may increase up to $500-600 \mathrm{mg} \cdot \mathrm{L}^{-1}$. It consists mainly of resuspended fine (particle size 0.2-10 $\mu \mathrm{m}$ ) mineral sediment and biogenic lime (Entz and Sebestyén, 1942; Entz, 1981; Somlyódy, 1986; G.-Tóth, 1999). The development of a thermocline and chemoclines, which are characteristic in deep lakes, is rare in Lake Balaton, being a typical polymictic lake. The whole water column is well oxygenated (Entz, 1981). The above observations allow the supposition that the vertical distribution of zooplankton assemblages and their migration takes 
place in a different way in Lake Balaton than that known from deep lakes. Thus, our aim was to observe vertical migration of Lake Balaton zooplankton assemblages with a detailed series of investigations, and to explore the relationship between current velocity and zooplankton diel vertical migration in shallow lakes.

\section{MATERIAL AND METHODS}

We investigated the effect of current velocity on the structure of zooplankton assemblages by sampling zooplankton and parallel measurements of RMS turbulence from April to October 2007 weekly, and on three occasions (4-5 August 2003, 25-26 August 2003 and 1819 September 2007, for the latter in two different sites in parallel) covering a complete 24-h period at one sampling point by sampling every $3-4 \mathrm{~h}$, on average.

\section{> WEEKLY SAMPLINGS}

Zooplankton samples were taken in the littoral zone, $25 \mathrm{~m}$ (GPS coordinates: $46^{\circ} 54^{\prime} 52.7^{\prime \prime} \mathrm{N}$, $17^{\circ} 53^{\prime} 36.3^{\prime \prime} \mathrm{E}$; depth: $2.2 \mathrm{~m}$ ) and $200 \mathrm{~m}$ (GPS coordinates: $46^{\circ} 54^{\prime} 51.4^{\prime \prime} \mathrm{N}, 17^{\circ} 53^{\prime} 46.4^{\prime \prime} \mathrm{E}$; depth: $3.3 \mathrm{~m}$ ) off the northern shore of Lake Balaton near the Limnological Research Institute at $0.5-\mathrm{m}$ increments through the water column with a $0.5-\mathrm{m}$-high Schindler-Patalas sampler (volume: $34 \mathrm{~L}$ ) equipped with a plankton net (mesh size $60 \mu \mathrm{m}$ ). Samples were concentrated to a volume of $100 \mathrm{~mL}$ and preserved with formaldehyde (end concentration of 3.5\%). Zooplankton organisms were identified and counted with a Zeiss-Opton inverted plankton microscope. At least 450 individuals were counted in three parallel sub-samples. Species were identified according to the identification guides of Gulyás and Forró (1999, 2001), Einsle (1993) and Flößner (2000). All densities are expressed in ind. $\mathrm{L}^{-1}$.

Current velocity was measured using a 3-D SonTek Acoustic Doppler velocimeter, parallel to taking zooplankton samples and at the same water depths. The Acoustic Doppler Velocimeter measures the vectorial components of the flow ( $x, y, z$ components). Data were evaluated with the program WinADV, using the RMS turbulence in $\mathrm{m} \cdot \mathrm{s}^{-1}$. The RMS turbulence is the root-mean-square of the turbulent velocity fluctuation. The RMS turbulence is equal to the standard deviation of the samples. WinADV computes the sample standard deviation. For example, the RMS turbulence for the $X$ velocity component is:

$$
R M S\left[V x^{\prime}\right]=\sqrt{\overline{\left(V x^{\prime}\right)^{2}}}=\sqrt{\frac{\sum V x^{2}-\left(\sum V x\right)^{2} / n}{n-1}} .
$$

The velocimeter does not directly measure turbulence but rather quantifies the variability in current velocity. Whether the reason for the fluctuations is turbulence or whether other forces are relevant is not measurable by the Acoustic Doppler Velocimeter. Therefore, the RMS has to be regarded rather as a proxy for turbulence than real turbulence. However, for the target of this research this is irrelevant, as zooplankton want to avoid shear, and thus velocity fluctuations.

\section{>24-H SAMPLINGS}

In 2003 (4-5 August 2003, 25-26 August 2003), the two 24-h studies were started after a long-lasting calm period approx. $800 \mathrm{~m}$ from the shoreline of the Limnological Research Institute (GPS coordinates: $46^{\circ} 54^{\prime} 48.77^{\prime \prime} \mathrm{N}, 17^{\circ} 53^{\prime} 56.39^{\prime \prime} \mathrm{E}$, water depth $2.7-2.8 \mathrm{~m}$ ) at noon. During these samplings RMS turbulence was not measured. The 24-h sampling in 2007 (1819 September 2007) was carried out at the two parallel sites of the weekly sampling. The sampling was chosen so that the effects of strong winds on the water current velocity and zooplankton assemblages could be observed. The storm, when the daily mean wind speed 
of $1.8 \mathrm{~m} \cdot \mathrm{s}^{-1}$ increased to above $11 \mathrm{~m} \cdot \mathrm{s}^{-1}$, started on the evening of the initial day between 8 and 9 p.m. On this occasion, sampling was completed with measurements of the RMS turbulence in different layers of the water body. The sampling method as well as the processing of the samples were identical to the methods used in the weekly samplings.

\section{> DATA PROCESSING}

To investigate the relationship between RMS turbulence and zooplankton, Canonical Correspondence Analysis was used, with the Syn-Tax program package (Podani, 1997) and linear regression was calculated with the statistical program $R$. The mean residence depth $(M R D)$, which is characteristic of the zooplankton populations, was determined according to Armengol and Miracle (2000) as

$$
M R D=\frac{\sum\left(N_{i} \times d_{i}\right)}{\sum N_{i}}
$$

where $N_{i}$ is the concentration of individuals at depth $i$ and $d_{i}$ is the depth of the $i$ th sample. The resulting value characterizes the imaginary "center of mass" of the population, showing the characteristic depth of the population at a certain time.

\section{RESULTS}

During the study periods, Eudiaptomus gracilis and Mesocyclops leuckarti were the most frequent among the Copepoda. The most abundant Cladocera species were a Daphnia cucullata $\times$ galeata hybrid (Nédli et al., 2005; hereinafter referred to as Daphnia) and Diaphanosoma brachyurum, and the most abundant rotifers were Keratella cochlearis, Polyarthra remata and Kellicottia longispina. Overall, nauplius larvae of the copepods occurred in the greatest numbers.

The most abundant zooplankton species were similar in 2003 and in 2007 (Table I).

During the weekly samplings in 2007, the RMS turbulence of Lake Balaton varied between 0.01 and $0.11 \mathrm{~m} \cdot \mathrm{s}^{-1}$. Most frequently $(32.7 \%)$ values were between 0.01 and $0.03 \mathrm{~m} \cdot \mathrm{s}^{-1}$. In $21.5 \%$ of cases the values were below $0.01 \mathrm{~m} \cdot \mathrm{s}^{-1}$, and exceeded $0.03 \mathrm{~m} \cdot \mathrm{s}^{-1}$ in $24.2 \%$ of the cases.

Analyzing the relation between RMS turbulence and total zooplankton (copepod and cladocer) densities, a significant, negative relationship was detected, which explained $36 \%$ of total variance in population densities (Figure 1).

The relationship between the density of the zooplankton species and the environmental parameters (water temperature, water depth and RMS turbulence) was analyzed based on the 2007 data at one sampling point (2.2-m water depth) with Canonical Correspondence Analysis, which explained $61 \%$ of total variance on the first axis and $29 \%$ on the second (Figure 2). The biplot shows that among the three environmental parameters, it is mainly water temperature and RMS turbulence which have the strongest effect. Among the dominant species, RMS turbulence had the greatest effect on Eudiaptomus gracilis, Daphnia sp., Kellicottia longispina and Dreissena polymorpha veliger larvae.

Eudiaptomus gracilis (copepodit stages I-V and adults) and Daphnia species were the most abundant taxa in the zooplankton assemblages, and according to the Canonical Correspondence Analysis these two taxa were the most sensitive to RMS turbulence.

The data for wind speed and RMS turbulence during the 24-h sampling in 2007 (1819 September) are shown in Figure 3. The storm began between 8-9 p.m. on the 18th. In this period, wind velocity suddenly rose from $1.8-3.5$ to $10.4-11.5 \mathrm{~m} \cdot \mathrm{s}^{-1}$, while current velocity increased from $0.02 \mathrm{~m} \cdot \mathrm{s}^{-1}$ to $0.042-0.07 \mathrm{~m} \cdot \mathrm{s}^{-1}$. Next morning, at 3-4 a.m., wind speed decreased to $2.5-3.9 \mathrm{~m} \cdot \mathrm{s}^{-1}$ and RMS turbulence values decreased slowly to $0.046-0.047 \mathrm{~m} \cdot \mathrm{s}^{-1}$. 


\section{Table I}

Species composition in 2003 and 2007 in the studied period.

Tableau I

Composition des espèces en 2003 et 2007 pendant la période d'étude.

\begin{tabular}{|l|l|l|}
\hline \multirow{5}{*}{ Rotatoria } & \multicolumn{1}{|c|}{2003} & \multicolumn{1}{|c|}{2007} \\
& Kellicottia longispina (Kellicott) & Brachionus sp. \\
& Keratella cochlearis (Goose) & Filinia terminalis Plate \\
& Keratella quadrata (O. F. Müller) & Kellicottia longispina (Kellicott) \\
& Keratella ticinensis (Callerio) & Keratella cochlearis (Goose) \\
& Polyarthra remata (Skorikov) & Keratella quadrata (O. F. Müller) \\
& & Polyarthra remata (Skorikov) \\
& & Pompholyx sp. \\
\hline Bivalvia & Dreissena polymorpha Pallas & Dreissena polymorpha Pallas \\
\hline Crustacea & Bosmina longirostris O. F. Müller & Alona affinis Leydig \\
& Cyclops vicinus Ulianine & Alona rectangula Sars \\
& Daphnia cucullata Sars & Bosmina coregoni O. F. Müller \\
& Diaphanosoma brachyurum Liévin & Bosmina longirostris O. F. Müller \\
& Eudiaptomus gracilis Sars & Cyclops vicinus Ulianine \\
& Leptodora kindtii Focke & Daphnia cucullata Sars \\
& Mesocyclops leuckarti Claus & Diaphanosoma brachyurum Liévin \\
& & Eudiaptomus gracilis Sars \\
& & Leptodora kindtii Focke \\
& & Leydigia sp. \\
& & Macrothrix hirsuticornis Norman and Brady \\
& & Mesocyclops leucarti Claus \\
\hline
\end{tabular}

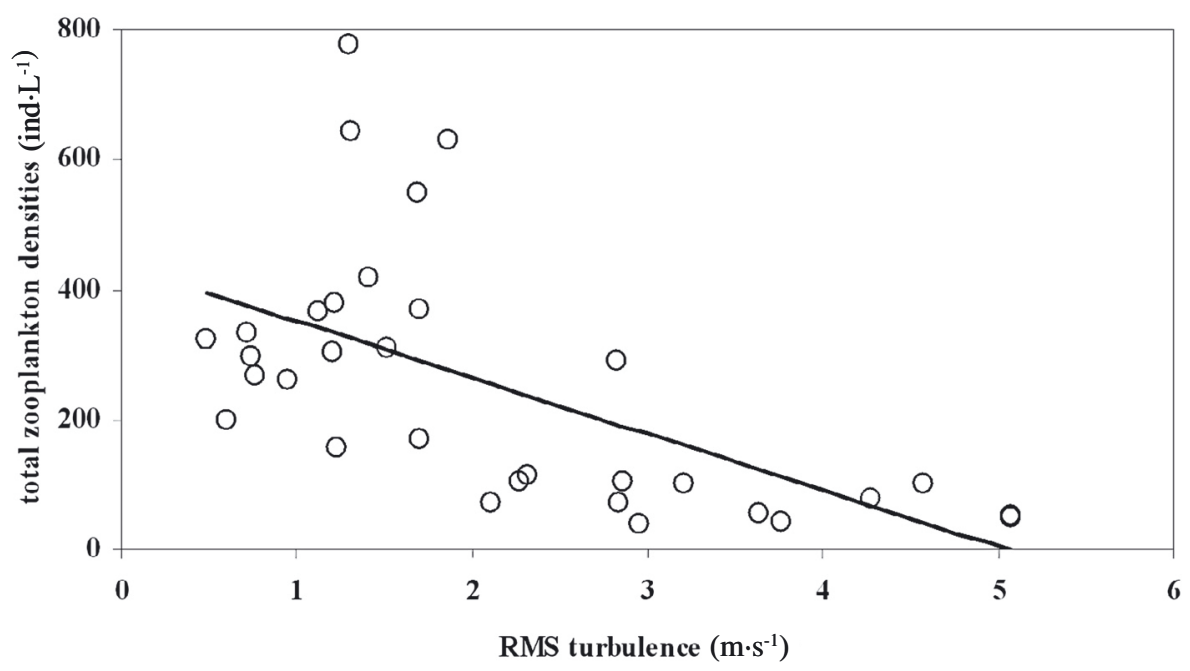

\section{Figure 1}

Linear regression between zooplankton densities and RMS turbulence values $(y=-0.004 x+3.169$, $r^{2}=0.34, F=15.96$, d.f. $=30, P<0.001$. 


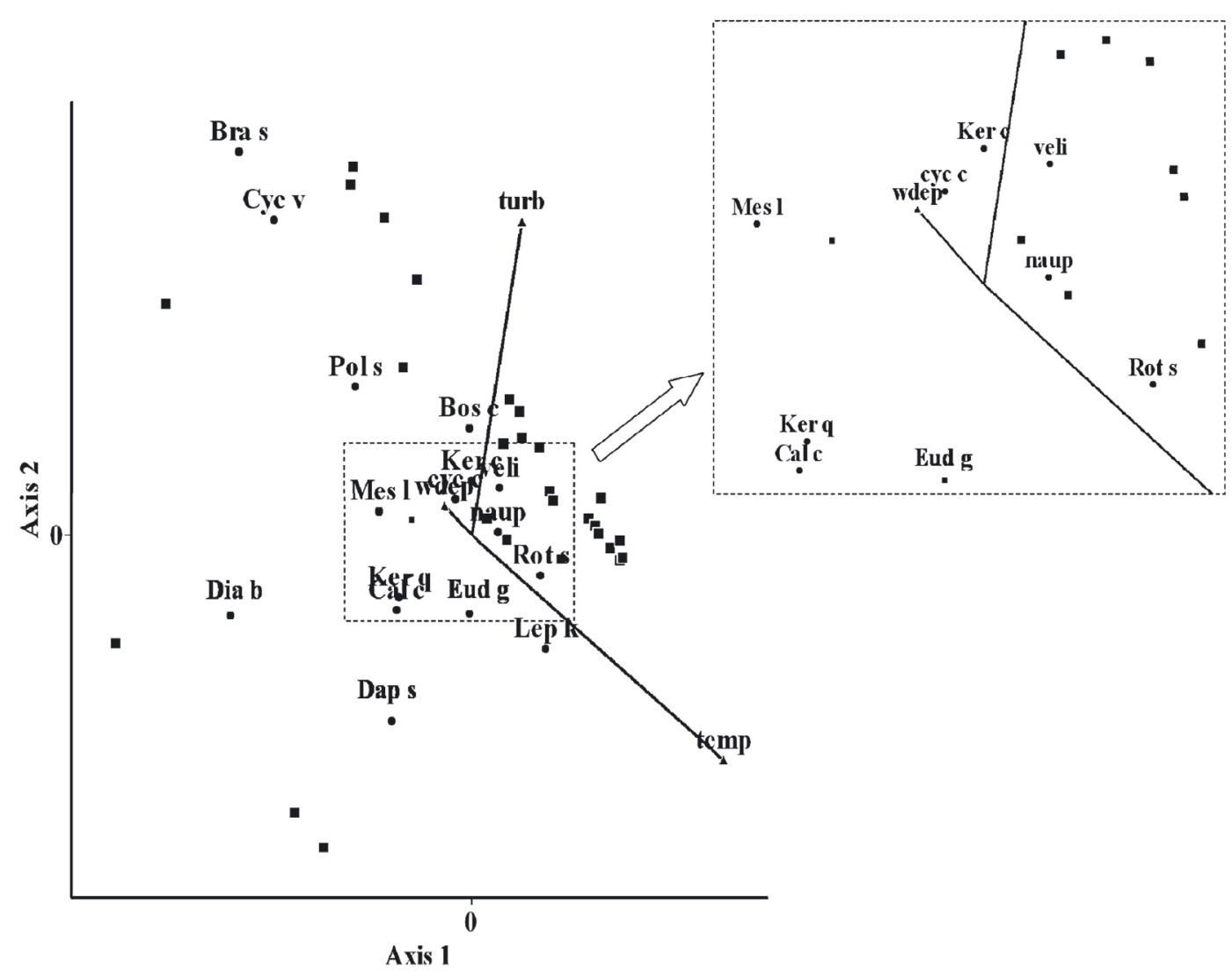

Figure 2

Relationship between environmental variables and zooplankton species, analyzed with Canonical Correspondence Analysis. (Legend: species: Bos $c=$ Bosmina coregoni, Cal c = Calanoida copepodit, Cyc $v$ = Cyclops vicinus, $c y c l c=$ Cyclopoida copepodit, Dap $s=$ Daphnia cucullata (cucullata $\times$ galeata), Dia $b=$ Diaphanosoma brachyurum, veli = Dreissena polymorpha veligera, Eud $g=$ Eudiaptomus gracilis, Lep $k$ = Leptodora kindtii, Mes $I=$ Mesocyclops leuckarti, naup = nauplius, Rot $s=$ Rotatoria sp., environmental variables: temp = temperature, turb $=R M S$ turbulence, wdep $=$ water depth.)

Figure 2

Relation entre les variables environnementales et les espèces zooplanctoniques, analyse par analyse canonique des correspondances. (Légende : espèces : Bos c = Bosmina coregoni, Cal c = Calanoida copepodit, Cyc v = Cyclops vicinus, cycl c = Cyclopoida copepodit, Dap s = Daphnia cucullata (cucullata $\times$ galeata), Dia b = Diaphanosoma brachyurum, veli = Dreissena polymorpha veligera, Eud $\mathrm{g}=$ Eudiaptomus gracilis, Lep $\mathrm{k}=$ Leptodora kindtii, Mes I = Mesocyclops leuckarti, naup = nauplius, Rot $\mathrm{s}=$ Rotatoria $\mathrm{sp}$., variables environmentales : temp = température, turb = RMS-turbulence, wdep = profondeur d'eau.)

Density changes of Daphnia sp. and Eudiaptomus gracilis in the different water layers during the 24-h sampling in 2003 (4-5 August 2003, 25-26 August 2003) and in 2007 (18-19 September 2007) are shown in Figures 4 and 5.

In 2003, in calm weather, the Daphnia populations in Lake Balaton were concentrated in the lower layers of the water column with the highest densities below $2.0 \mathrm{~m}$, in general (Figure 4). In the evening (from 11 p.m. until 3 a.m.), Daphnia was evenly distributed across the whole water column. In the morning (from 7 a.m. until 10 a.m.), Daphnia densities started to increase in the lower water layers, and during the day the upper layers became less and less populated by Daphnia. MRD values underlined the pattern described above. The lower MRD values were observed at 3 and at 7 p.m. at 1.95 and $1.99 \mathrm{~m}$, respectively, and the higher values during the night and early in the morning (Figures $4 a$ and $4 b$ ). 


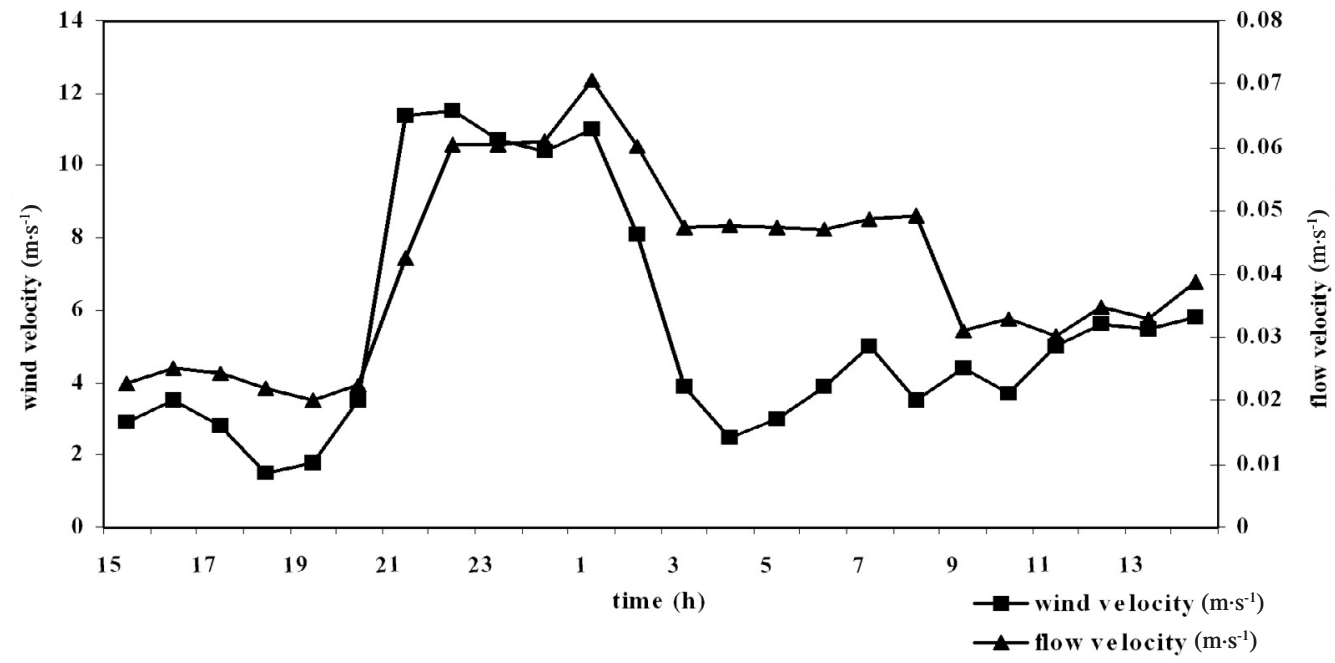

\section{Figure 3}

Changes in the wind speed and RMS turbulence during the 24-h sampling (on 18-19 September 2007).

Figure 3

Changements dans la vitesse du vent et la turbulence RMS pendant le suivi de 24 h les 18-19 septembre 2007.

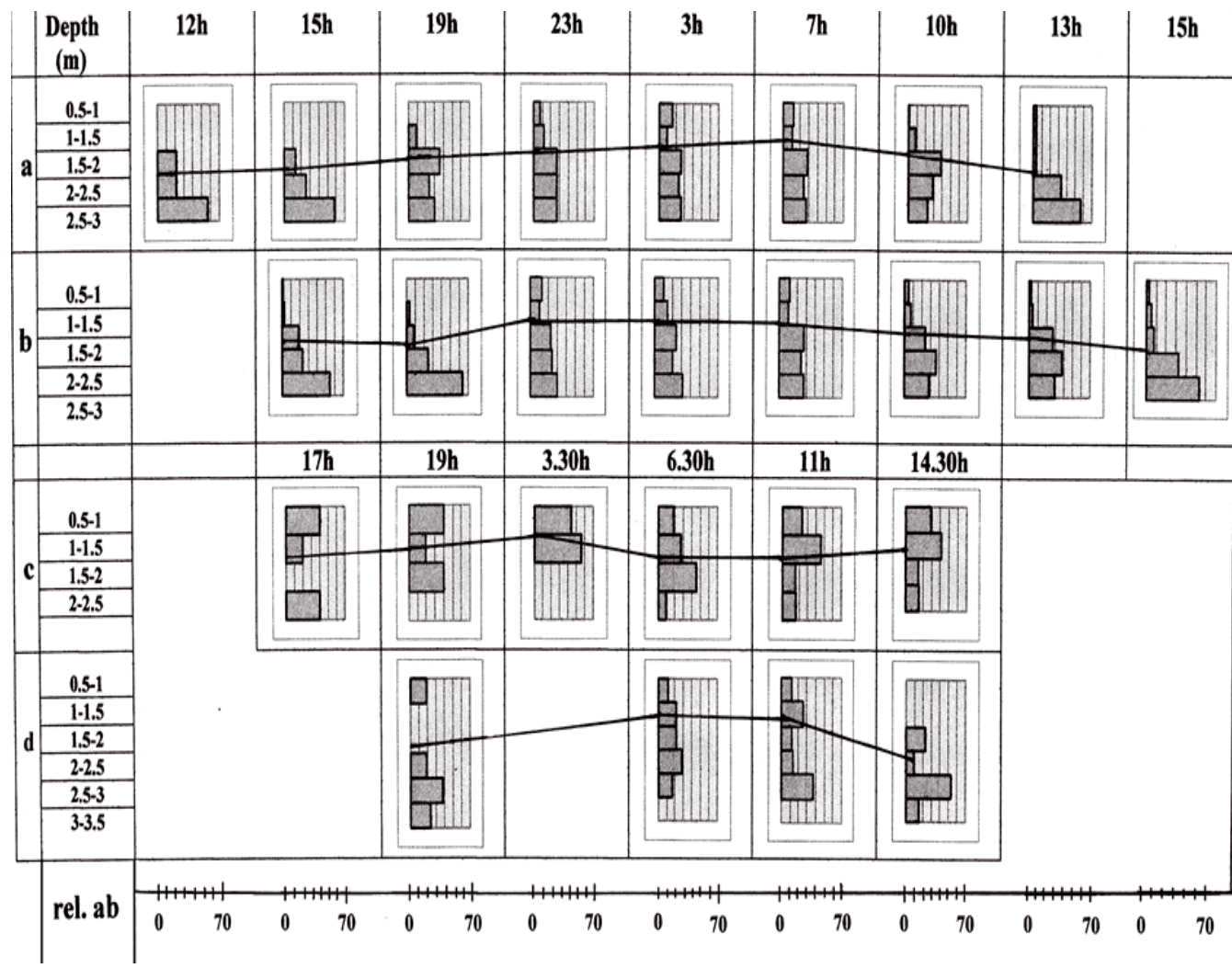

\section{Figure 4}

Vertical migration of Daphnia sp.; $a$ and $b=$ the two courses of sampling in 2003 in calm weather; $c$ and $d=$ the two courses of sampling in 2007 when the storm arrived; solid line $=M R D$.

\section{Figure 4}

Migration verticale de Daphnia sp. ; a et b = les deux séries d'échantillonnage en 2003 en période calme, $c$ et d = les deux séries d'échantillonnage en 2007 quand la tempête arrive; ligne = MRD. 


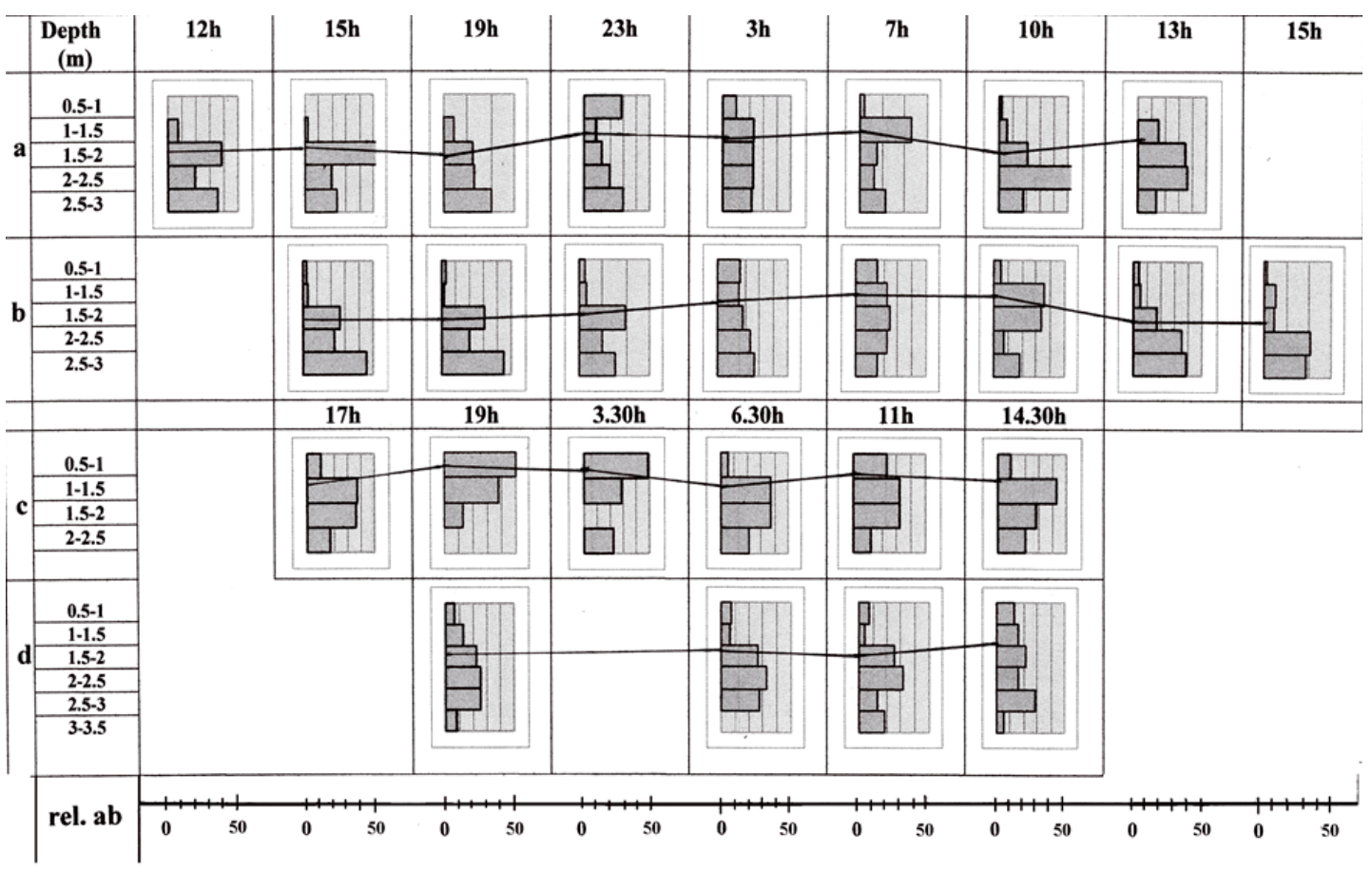

\section{Figure 5}

Vertical migration of copepodits and adults of Eudiaptomus gracilis; $a$ and $b=$ the two courses of sampling in 2003 in calm weather; $c$ and d = the two courses of sampling in 2007 when the storm arrived; solid line $=$ MRD.

\section{Figure 5}

Migration verticale des copépodites et des adultes d'Eudiaptomus gracilis; $a$ et $b=$ les deux séries d'échantillonnage en 2003 en période calme, c et d = les deux séries d'échantillonnage en 2007 quand la tempête arrive; ligne $=$ MRD.

In 2007 (18-19 September 2007) at the 2.2-m-deep sampling site, the densities in the uppermost and middle layers increased between 5 and 7 p.m., whereas the densities in the lowest layer dropped to zero. After the storm, at 3.30 a.m., the Daphnia population stayed in the uppermost $1.5 \mathrm{~m}$. In the morning (at 6.30 a.m.), zooplankton densities became more even, but were still the highest in the upper 1.5-m layer (Figure 4c).

In 2007 (18-19 September 2007) at the 3.3-m-deep sampling point before the storm at 7 p.m., the majority of the animals were found in the lowest, 2-3.5-m-deep water layer, but some specimens were found in the upper 0.5-1-m layer. In the morning (from 6.30 a.m.) hours after the storm, zooplankton was almost evenly distributed across the whole water column, and this was still the case at 11 a.m. Only at 2.30 p.m. was higher zooplankton density found in the bottom layers. MRD values were low $(1.44 \mathrm{~m})$ after the storm at $11 \mathrm{a} . \mathrm{m}$. This was the sampling site and time when the greatest difference in minimum and maximum MRD values $(0.72 \mathrm{~m}$ ) was observed (Figure $4 \mathrm{~d})$.

Densities of copepodit larvae and adults of Eudiaptomus gracilis during the 24-h study in August 2003 (4-5 August 2003, 25-26 August 2003) were highest in the daytime in the lower and middle layers of the water column, e.g. at 3 p.m. more than $50 \%$ of the individuals stayed in the 1-1.5-m layer. Their density was very low in the uppermost layer; at 12 a.m. and 7 p.m. and on 4th August no individuals were found in the sample from the upper $0.5 \mathrm{~m}$. After sunset, a significant change took place in the vertical structure of the population. In the upper layer a great number of individuals appeared, and for the night the distribution of the population 
became even. This tendency was in accordance with the MRD values, which varied between 1.49 and $1.77 \mathrm{~m}$ during the day and between 1.25 and $1.58 \mathrm{~m}$ in the night (Figures $5 \mathrm{a}$ and $5 \mathrm{~b}$ ). In 2007 (18-19 September 2007) at the 2.2-m-deep sampling point before the storm at 5 p.m. the highest density was observed in the middle, 1-2-m-deep water layers, but some animals were found in each layer. From 7 p.m. till 3.30 a.m., the majority of the E. gracilis population stayed in the uppermost 1.5-m layer, and in the morning (at 6.30 a.m.) their density was greatest between 1 and $2 \mathrm{~m}$, but there was also a great number of animals in the upper 1-m layer. The MRD values decreased on the day after the storm until midday, showing a concentration in the upper layers (Figure 5c).

In 2007 (18-19 September 2007) at the 3.3-m sampling point before the storm at 7 p.m. animals were found all across the water column, with the greatest density between 1.5 and $3 \mathrm{~m}$. This structure persisted until the next midday. MRD values changed between 1.49 and $1.72 \mathrm{~m}$, with the lowest value at 2.30 p.m. after the nocturnal storm (Figure 5d).

\section{DISCUSSION}

This study on RMS turbulence and zooplankton demonstrated a highly significant, negative relation between these two variables. From the studied assemblages it is Daphnia galeata $\times$ cucullata and Eudiaptomus gracilis which showed the greatest sensitivity to the degree of RMS turbulence.

On days with calm weather, nocturnal migration was observed in Daphnia galeata $\times$ cucullata and Eudiaptomus gracilis. They were concentrated in deeper water layers (2-3 m) during the day and exhibited rather equal distribution in the night, which can also be seen on the pattern of the MRD values. Earlier results reported similar patterns (Sebestyén, 1933; Ponyi and Péter, 1986).

In studies on the E. gracilis population in Lake Balaton (Ponyi and Péter, 1986) nocturnal migration was observed both for copepodit stages and adults, supporting observations of other authors (e.g. Ringelberg et al., 1991). According to Ponyi and Péter (1986), the E. gracilis population in Lake Balaton occupies the middle layers during the day, while towards night the vertical distribution of the population becomes equalized. The present study shows, however, that while $E$. gracilis is frequently found in the middle layers during the day, its density can be even higher in deeper layers. The difference between our two studies might be explained by the different water levels, which were 3.4-3.5 m during the study in 2003 and were only 2.7-2.8 $\mathrm{m}$ in our study. If migration is indeed mainly regulated by light, the organisms relate their position to the water surface; thus the optimal region for them during the day gets closer to the bottom.

As the present study was the first to investigate the vertical migration of Daphnia in Lake Balaton, we can only compare our results with those obtained in other lakes. The majority of the studies report on nocturnal migration as described above for Daphnia (Worthington, 1931; Loose, 1993; Davidson and Kelso, 1997; Ramos-Jiliberto and Zúñiga, 2001). It was observed that especially smaller sized planktonic organisms (e.g. Bosmina sp., rotifers) exhibit reversed migration in lakes with no fish. The reversed migration is often explained by predation by invertebrates with nocturnal migration (Ohman et al., 1983; Levy, 1990; Alajärvi and Horppila, 2004). This assumption is supported by the fact that Neill (1990) found that the reversed migration of plankton turns nocturnal again, once the invertebrate predator has been removed by fish introduced accidentally. This phenomenon was observed for bigger sized cladocerans, too (e.g. for Daphnia by Bayly (1986)). However, to decide whether nocturnal migration is the basic migration strategy of Daphnia in Lake Balaton or whether it is only initiated by fish or invertebrate predation is a question leading much further and should be part of another study. The obtained results show that vertical stratification and nocturnal vertical migration of zooplankton develop in the shallow Lake Balaton in calm periods. Conditions like this are rare in the lake, as on the one hand even light wind is sufficient to induce waves and RMS turbulence in such a shallow lake, and on the other hand, days with moderate to strong wind occur 
frequently. Our own measurements as well as data from the literature show that Lake Balaton is hydrodynamically highly kinetic: wind speeds of $>4 \mathrm{~m} \cdot \mathrm{s}^{-1}$ occur statistically on every 3rd day, stirring up the sediment, and winds of $>10 \mathrm{~m} \cdot \mathrm{s}^{-1}$ occur 12 times per year (Entz, 1981; Szilágyi et al., 1981; Hungarian National Meteorological Service). Since turbulence intensity depends not only on the energy input flux imposed by the wind but also on the available vertical space for energy dissipation (Reynolds, 1992), it is an extremely effective force in the shallow Lake Balaton. Similarly, for Lake Suwa (Japan), where the average depth is $4.7 \mathrm{~m}$, considerable resuspension has been measured at wind speeds of $4 \mathrm{~m} \cdot \mathrm{s}^{-1}$ (Hilton, 1985). According to Felföldy (1981), a wind of $5 \mathrm{~m} \cdot \mathrm{s}^{-1}$ induces flow velocities of $0.02-0.04 \mathrm{~m} \cdot \mathrm{s}^{-1}$ in Lake Balaton. During our weekly studies for two years, RMS turbulence exceeded the upper value given above $\left(0.04 \mathrm{~m} \cdot \mathrm{s}^{-1}\right)$ in $24 \%$ of the cases. A long-lasting wind of $4 \mathrm{~m} \cdot \mathrm{s}^{-1}$ induces a significant increase in suspended solids, to about $10-30 \mathrm{mg} \cdot \mathrm{L}^{-1}$ (Entz, 1981). This means that - depending on the direction of the wind, and thereby on the fetch length and depth of water (Harding, 1997) - wind and flow velocities which are sufficient for reaching the bottom and mixing it up are quite common. An increase in suspended solids has diverse inhibitory effects on filter-feeders (Entz and Sebestyén, 1942; G.-Tóth, 1984). Detrimental effects might also occur by the changed optical qualities of the water body. Apart from the increased turbidity, the movement of water itself influences aquatic organisms: on the one hand by turbulent shear forces, which damage the sensitive plankton organisms physically (Visser and Stips, 2002; Visser et al., 2009), and on the other hand by simply transporting them and thus rearranging their horizontal and vertical structure (together with great masses of water in the wind direction (Felföldy, 1981)). High turbulence also interferes with the feeding current of suspension-feeders, erodes the remote detection of floating prey by their predators, inhibits food ingestion and increases their metabolic energy expenditure (Rotschild and Osborn, 1988; Reynolds, 1992; Visser and Stips, 2002; Visser et al., 2009).

An obvious, disturbing effect of the starting wind on the vertical structure and migration pattern of the zooplankton in Lake Balaton was observed in the 24-h sampling in 2007. We showed that the vertical migration of two dominant crustacean taxa started before the storm as usual nocturnal migration, but this pattern was interrupted. At both sampling sites, MRD values differed from those characteristic for nocturnal migrations: values decreased during the night, increased in the morning of the day following the nocturnal storm, and decreased again around noon.

Following the MRD values, we can see that during and after the storm, the usual dispersion in the water layers did not take place in the night, and in the morning hours most of the animals were still in the upper two meters of the water column instead of retreating to the bottom.

A rapid change in the transporting cycles of planktonic organisms at enhanced wind speeds was also demonstrated by Denman and Gargett (1983) for oceanic conditions. It is easily conceivable that in much shallower waters, like in Lake Balaton, such processes are even more sensitive to wind-induced changes in currents.

There were also some differences in zooplankton densities in the different water layers between the two sampling sites with 2.2-m and 3.3-m depths: in deeper water the animals were more equally distributed, while in shallower water the majority of the animals stayed between 1 - and 1.5-m depth. This shows, that - (probably) through changes in the depth of the wave base (Harding, 1997) - the effect of wind and RMS turbulence on zooplankton organisms is influenced by the water depth.

\section{ACKNOWLEDGEMENTS}

We thank Prof. Judit Padisák for her help. This study was financially supported by the Hungarian National Research Fund (OTKA No.: T17-49365) and National Research and Development Project (BALÖKO). 


\section{REFERENCES}

Alajärvi E. and Horppila J., 2004. Diel variations in the vertical distribution of crustacean zooplankton and food selection by planktivorous fish in a shallow turbid lake. International Review of Hydrobiology, 89, 238-249.

Armengol X. and Miracle M.R., 2000. Diel vertical movements of zooplankton in lake La Cruz (Cuenca, Spain). J. Plankton Res., 22, 1683-1703.

Bayly I.A.E., 1986. Aspects of diel vertical migration in zooplankton, and its enigma variations. In: Dedeccker P. and Williams W.D. (eds.), Limnology in Australia, Commonwealth Scientific and Industrial Research Organisation, Melbourne, 349-386.

Cushing D.H., 1951. The vertical migration of planktonic Crustacea. Biol. Rev., 26, 158-192.

Daday J., 1884. The secrets of Lake Balaton (in Hung.). Orvos-Természettudományi Értesítõ, 6, 69-95.

Davidson N.L. and Kelso W.E., 1997. The exotic daphnid, Daphnia lumholtzi, in a Louisiana river-swamp. J. Freshwater. Ecol., 12, 431-435.

De Meester L., 1993. Genotype, fish-mediated chemicals, and phototactic behavior in Daphnia magna. Ecology, 74, 1467-1474.

Denman K.L. and Gargett A.E., 1983. Time and space scales of vertical mixing and advection of phytoplankton in the upper ocean. Limnol. Oceanog., 28, 801-815.

Easton J. and Gophen M., 2003. Diel variation in the vertical distribution of fish and plankton in Lake Kinneret: a 24-h study of ecological overlap. Hydrobiologia, 491, 91-100.

Einsle U., 1993. Crustacea Copepoda Calanoida und Cyclopoida, Gustav Fischer Verlag, Stuttgart, Jena, New York.

Entz B., 1981. Windgeschwindigkeit, Schwebstoffmengen und Lichtverhältnisse im Balatonsee. BFBBericht, 42, 69-78.

Entz G. and Sebestyén O., 1942. The life of Lake Balaton (in Hung.), Királyi Magyar Természetudományi Társulat, Budapest.

Felföldi L., 1981. The ecology of waters: general hydrobiology (in Hung.), Mezõgazdasági Kiadó, Budapest.

Flößner D., 2000. Die Haplopoda und Cladocera Mitteleuropas, Backhuys Publishers, Leiden.

Folt C.L. and Burns C.W., 1999. Biological drivers of zooplankton patchiness. Trends Ecol. \& Evol., 14, 300-305.

George D.G., 1983. Interrelations between the vertical distribution of Daphnia and chlorophyll a in two large limnetic enclosures. J. Plankton Res., 5, 457-475.

George D.G. and Winfield I.J., 2000. Factors influencing the spatial distribution of zooplankton and fish in Loch Ness, UK. Freshw. Biol., 43, 557-570.

Gulyás P. and Forró L., 1999. A short identification key to the Cladocera (in Hung.), Környezetgazdálkodási Intézet, Budapest.

Gulyás P. and Forró L., 2001. A short identification key to the Cladocera (in Hung.), Környezetgazdálkodási Intézet, Budapest.

G.-Tóth L., 1984. Feeding behaviour of Daphnia cucullata Sars in the easily stirred up Lake Balaton as established on the basis of gut content analyses. Arch. Hydrobiol., 101, 531-553.

G.-Tóth L., 1999. The role of crustacean assemblages in eliminating phytoplankton and providing fish (in Hung.), Closing report on the research activity of 1999 by order of the Prime Minister's Office and of the Hungarian Academy of Science, Tihany, 1-86.

Harding W.R., 1997. Phytoplankton primary production in a shallow, well-mixed, hypertrophic South African lake. Hydrobiologia, 344, 87-102.

Hilton J., 1985. A conceptual framework for predicting the occurrence of sediment focusing and sediment redistribution in small lakes. Limnol. Oceanog., 30, 1131-1143.

Hülsmann S., Vijverberg J., Boersma M. and Mooij W.M., 2004. Effects of infochemicals released by gape-limited fish on life history traits of Daphnia: a maladaptive response? J. Plankton Res., 26, 535-543.

Hutchinson G.E., 1967. A Treatise on Limnology, Vol. II, John Wiley \& Sons Inc., New York, London, Sydney, 725-788. 
Kvam O.V. and Kleiven O.T., 1995. Diel horizontal migration and swarm formation in Daphnia in response to Chaoborus. Hydrobiologia, 307, 177-184.

Lampert W., McCauley E. and Manly B.F.J., 2003. Trade-offs in the vertical distribution of zooplankton: ideal free distribution with costs? Proc. Royal Soc. Biol. Sci., 270, 765-773.

Levy D.A., 1990. Reciprocal diel vertical migration behavior in planktivores and zooplankton in British Columbia lakes. Can. J. Fish. Aquat. Sci., 47, 1755-1764.

Loose C.J., 1993. Daphnia diel vertical migration behavior: Response to vertebrate predator abundance. Arch. Hydrobiol. Beih., 39, 29-36.

Megard R.O., Kuns M.M., Whiteside M.C. and Downing J.A., 1997. Spatial distributions of zooplankton during coastal upwelling in western Lake Superior. Limnol. Oceanog., 42, 827-840.

Moore M.V., Pierce S.M., Walsh H.M., Kvalvik S.K. and Lim J.D., 2000. Urban light pollution alters the diel vertical migration of Daphnia. Verh. Internat. Verein. Limnol., 27, 1-4.

Nédli J., Forró L., Korponai J. and G.-Tóth L., 2005. Daphnia species (Crustacea, Cladocera) and the genetic characteristics of their populations based on allozyme studies in Lake Balaton, Hungary. Opusc. Zool., 36, 79-84.

Neill W.E., 1990. Induced vertical migration in copepods as a defence against invertebrate predation. Nature, 345, 524-526.

Ohman M.D., Frost B.W. and Cohen E.B., 1983. Reverse diel vertical migration: an escape from invertebrate predators. Science, 220, 1404-1407.

Podani J., 1997. Introduction in the enigma of multivariance analyses (in Hung.), Scientia Kiadó, Budapest, 1-412.

Ponyi J. and Péter L.H., 1986. The diel vertical migration of Eudiaptomus gracilis (G. O. Sars) in Lake Balaton (in Hung.). Állattani Közlemények, 73, 69-77.

Ponyi J. and Tamás G., 1964. Studies on the diel changes in phyto- and zooplantkon of the Inner Lake at Tihany (in Hung.). Állattani Közlemények, 51, 105-124.

Ramos-Jiliberto R. and Zúñiga L.R., 2001. Depth-selection patterns and diel vertical migration of Daphnia ambigua (Crustacea: Cladocera) in lake El Plateado. Revista Chilena De Historia Natural, 74, 573-585.

Raymont J.E.G., 1983. Plankton and productivity in the oceans, second edition, Vol. 2: Zooplankton, Pergamon Press, Oxford, New York, Toronto, Sydney, Paris, Frankfurt, 1-824.

Reynolds C.S., 1992. The role of fluid motion in the dynamics of phytoplankton in lakes and rivers. In: Giller P.S., Hildrew A.G. and Raffaelli D.G. (eds.), Aquatic ecology, scale, pattern and process, The 34th Symposium of the British Ecol. Soc. Univ. Coll. Blackwell, Oxford.

Ringelberg J., 1987. Light induced behaviour in Daphnia. In: Peters R.H. and De Bernardi R. (eds.), Daphnia, 285-323.

Ringelberg J., 1999. The photobehaviour of Daphnia spp. as a model to explain diel vertical migration in zooplankton. Biol. Rev., 74, 397-423.

Ringelberg J., 2000. The role of infochemicals in lake plankton crustacean behavior and predator-prey relations. In: von Vaupel Klein J.C. and Schram F.R. (eds.), The biodiversity crisis and crustacea, Proceedings of the Fourth International Crustacean Congress, Amsterdam, Netherlands, 20-24 July 1998, Volume 2, A.A. Balkema, Rotterdam, Brookfield, 161-174.

Ringelberg J., Flik B.J.G., Lindenaar D. and Royackers K., 1991. Diel vertical migration of Eudiaptomus gracilis during a short summer period. Hydrobiol. Bull., 25, 77-84.

Rinke K., Hübner I., Petzoldt T., Rolinski S., König-Rinke M., Post J., Lorke A. and Benndorf J., 2007. How internal waves influence the vertical distribution of zooplankton. Freshw. Biol., 52, 137-144.

Rothschild B.J. and Osborn T.R., 1988. Small-scale turbulence and plankton contact rates. J. Plankton Res., 10, 465-474.

Sebestyén O., 1933. The diel vertical migration of Leptodora kindtii Focke (Crustacea; Cladocera) and factors influencing it in Lake Balaton (in Hung.). MBKM, 6, 104-118.

Somlyódy L., 1986. Wind induced sediment resuspension in shallow lakes, Internat. Conf. on water quality modeling in the inland natural environment, Bournemouth, England, 10-13 June 1986, BHRA, The Fluid Engineering Centre, Cranfield, Bedford, MK430 j, England, 287-298.

Stich H.B. and Lampert W., 1981. Predator evasion as an explanation of diurnal vertical migration by zooplankton. Nature, 293, 396-398. 
Szilágyi F., Tóth L. and Hoffmann L., 1981. The effect of resuspension on some of the particulate componens present in the water of Lake Balaton. Hydraul. Eng., 4, 295-304.

Tátrai I. and de Bernardi R., 1992. Indirect impact of cyprinid fish fry on the growth and fecundity of Daphnia obtusa. Arch. Hydrobiol., 125, 371-381.

Van Donk E., 2006. Food-web interactions in lakes: What is the impact of chemical information conveyance? In: Dicke M. and Takken W. (eds.), Chemical Ecology: from gene to ecosystem, Springer, 145-160.

Van Gool E. and Ringelberg J., 1998. Light-induced migration behaviour of Daphnia modified by food and predator kairomones. Anim. Behav., 56, 741-747.

Visser A.W. and Stips A., 2002. Turbulence and zooplankton production: insights from PROVESS. J. Sea Res., 47, 317-329.

Visser A.W., Mariani P. and Pigolotti S., 2009. Swimming in turbulence: zooplankton fitness in terms of foraging efficiency and predation risk. J. Plankton Res., 31, 121-133.

Wetzel R.G., 1975. Limnology, W.B. Saunders Company, 1-742.

Worthington E.B., 1931. Vertical movements of freshwater macroplankton. Int. Rev. Hydrobiol., 25, 394436.

Zaret T.M. and Suffern J.S., 1976. Vertical migration in zooplankton as a predator avoidance mechanism. Limnol. Oceonog., 21, 804-813. 